\title{
Lead and Cadmium Toxicity on Seedling Growth and Metabolism of Trigonella foenum-graecum L.
}

\author{
Mallika Mukherjee
}

Department of Botany, UGC Centre of Advanced Study, The University of Burdwan, Golapbag, Burdwan-713104, West Bengal, India

\begin{abstract}
The present experiment was carried out to investigate the toxic effect of lead and cadmium on seedling growth and metabolism of medicinally important plant Trigonella foenum-graecum L. Physio-morphological changes was studied at early seedling growth under different concentrations $(5,10,15 \mathrm{mg} / \mathrm{l})$ of lead and cadmium. This metal showed toxic effect on seedling length, rootshoot ratio, dry weight accumulation, seedling vigour index. On the other hand, content of photosynthetic pigments viz. chlorophyll a, chlorophyll $b$ and carotenoid were decrease in a dose dependent manner in both heavy metal solution. The content of total free amino acids, soluble proteins and soluble and insoluble carbohydrate were initially increased as compared to control but at higher concentration in both the metal treatment showed decreased in content. Oxidative stress induced by heavy metals in plant causing membrane injury as observed by enhanced level of malondialdehyde (MDA) and in all experiments, higher concentration of cadmium showed the maximum toxicity as compared to lead.
\end{abstract}

Keywords: Lead, cadmium, seedling vigour index, Trigonella foenum-graecum L., malondialdehyde (MDA)

\section{Introduction}

Heavy metals are defined as metals with a density higher than $5 \mathrm{gcm}^{-3}$. Because they cannot be degraded or destroyed, heavy metals are persistent in all parts of the environment. Many heavy metals are naturally present in the environment. Various industrial activities which was widespread nowadays, arises environmental pollution by heavy metals (Arvind and Prasad, 2005).

Presence of heavy metals like $\mathrm{Cd}, \mathrm{Cu}, \mathrm{Pb}, \mathrm{Cr}, \mathrm{Hg}, \mathrm{Ni} \& \mathrm{Co}$ in air, soil and water affect the entire ecosystem through bioaccumulation resulting hazardous health consequences in all life forms (Sethy and Ghosh, 2013). Plants growing on metal polluted sites exhibit altered metabolism, growth reduction, lower biomass production and metal accumulation. Lead and cadmium are more hazardous, nonessential and important pollutant among various heavy metals. Interaction of lead and cadmium ions with the functional groups of proteins, nucleic acids and polysaccharides and substitution of other metal ions already bound to these functional groups by these two ions can lead to metabolic disorders and reduction in growth (Costa and Spitz, 1997; Seregin and Ivanov, 2001).

Trigonella foenum - graecum L. (fenugreek) or commonly as 'methi' is an important spice as well as medicinal plant and cultivated as annual, winter legume in India, can be grown easily in low-input, marginal environment, and are promising sources of calories, proteins, B-vitamins and minerals. It is cultivated mainly in India, Pakistan, Bangladesh, Argentina, Egypt, France, Yemen, Spain, Turkey, Morocco and China and India is the largest producer in the world ( Basu, 2006). The plant is aromatic, herbaceous, annual herbs and a self pollinated. Every part of this plant is utilized as leafy vegetables, fodder and condiments (Nadkarni, 1976). The seeds contain major alkaloid trigonelline which produced hypoglycaemic activity (Shani et al., 1974) and diosgenin. Fenugreek seeds can be considered as good supplement to sereals because of its high protein, lysine, insoluble and soluble dietary fiber and also rich in calcium, iron and beta-carotene (NIN report, 1987). Hence in the present investigation, the effect of lead and cadmium onmethihas been monitored in terms of morphological and physio-biochemical responses at early seedling growth.

\section{Material and Methods}

The seeds of Trigonella foenum-graecum L. cv. Pusa Early Branching were collected from the Maharashtra State Seeds Corporation Ltd., Mahabeej Bhavan, Krisna Nagar, Akola.

Different concentrations (5, 10 and $15 \mathrm{mg} / \mathrm{L})$ of $\mathrm{Pb}\left(\mathrm{NO}_{3}\right)_{2}$ and $\mathrm{CdCl}_{2}$ solutions were prepared with sterile double distilled water. For the control set (0) only pure double distilled water was used.

Healthy dry seeds $\rightarrow 0.1 \% \mathrm{HgCl}_{2}$ for 90 seconds.(surface sterilization) $\rightarrow$ soaked in different test solutions and control with 3 replications for $11 \mathrm{hrs}$. $\rightarrow 20$ seeds kept in each Petri dish lined with double layer of filter paper (Whatman No. 1 ) at $23 \pm 1^{0} \mathrm{C}$.

\subsection{Estimation of plant growth and biochemical} parameters:

Germinated seeds were transferred to the plastic pots containing sterilized sand - saw dust (6:4) mixture. Data on growth parameters such as seedling length, root-shoot ratio, dry weight accumulation, seedling vigour index were recorded in 15 days old seedlings.

2.2 Analysis of chlorophyll a, chlorophyll b and carotenoid:

Chlorophyll pigments were extracted and estimated according to the formulas of Lichtentaler and Wellburn (1985) slightly modified by Dere et al. (1998). 100mg of fresh leaves were homogenized using $5 \mathrm{ml}$ of $95 \%(\mathrm{v} / \mathrm{v})$ methanol. The green slurry was centrifuged at 4000rpm for 


\section{International Journal of Science and Research (IJSR) \\ ISSN (Online): 2319-7064}

Index Copernicus Value (2015): 78.96 | Impact Factor (2015): 6.391

10 minutes. The supernatant was taken in the test tubes. The residual pigments were re-extracted using $5 \mathrm{ml}$ of same methanol and centrifuged as same as earlier. This supernatant was added to the previously collected supernatant. The optical density was recorded at $666 \mathrm{~nm}$, $653 \mathrm{~nm}$ and $470 \mathrm{~nm}$ against $95 \%(\mathrm{v} / \mathrm{v})$ methanol as blank in UV - Visible Spectrophotometer. Chlorophyll and carotenoid contents were expressed in $\mathrm{mg} / \mathrm{g}$ of fresh weight. The amount of pigments present in the pigment extract was determined employing the following formulas:

$\mathrm{C}_{\mathrm{a}}=15.65 \times \mathrm{A}_{666}-7.340 \times \mathrm{A}_{653}$

$\mathrm{C}_{\mathrm{b}}=27.05 \times \mathrm{A}_{653}-11.21 \times \mathrm{A}_{666}$

$\mathrm{C}_{\mathrm{x}+\mathrm{c}}=1000 \times \mathrm{A}_{470}-2.860 \times \mathrm{C}_{\mathrm{a}}-129.2 \times \mathrm{C}_{\mathrm{b}} / 245$

$\left[\mathrm{C}_{\mathrm{a}}=\right.$ chlorophyll $\mathrm{a}, \mathrm{C}_{\mathrm{b}}=$ chlorophyll $\mathrm{b}, \mathrm{C}_{\mathrm{x}+\mathrm{c}}=$ total carotenoid.

\subsection{Estimation of total free amino acid and total soluble protein:}

Freshly collected $100 \mathrm{mg}$ leaf samples were homogenized with $80 \%$ boiling ethanol and then centrifuged at $5000 \mathrm{rpm}$ for 10 minutes.

Quantitative analysis of total free amino acids was done by the following method of Moore and stein (1948), modified by Bhattacharjee (1984) using ether and $0.1 \% \%$ ninhydrin solution. The absorbance of the solution was measured with a UV-Visible spectrophotometer at $580 \mathrm{~nm}$. The quantitative estimation was made by using the OD values from a standard curve prepared from glycine. Total free amino acids contents were expressed in $\mathrm{mg} / \mathrm{g}$ fresh weight.

Quantitative analysis of total protein was done by the following method of Kar and Mishra (1976) using 10\% (w/v) cold trichloroacetic acid (twice), ethanol (once), ethyl alcohol:chloroform $(3: 1, \mathrm{v} / \mathrm{v}$,$) , ether, \mathrm{NaOH}$ and finally the Folinciocalteau reagent and measuring the OD values at $650 \mathrm{~nm}$ according to the method of Lowry et al. (1951). Quantitative determination was made by comparing the OD values with a standard curve previously prepared using Bovine serum albumin (BSA). Content of protein was expressed as $\mathrm{mg} / \mathrm{g}$ of fresh weight.

\subsection{Estimation of soluble and insoluble carbohydrate:}

Quantitative analysis of soluble and insoluble carbohydrate was determined by the method of Mc Cready et al. (1950), after modifications. $100 \mathrm{mg}$ of fresh leaf tissues were thoroughly homogenized using $5 \mathrm{ml}$ boiling $80 \%$ ethanol and centrifuged at $5000 \mathrm{rpm}$ for 10 minutes. After dilution of the supernatant, for soluble carbohydrate analysis, $1 \mathrm{ml}$ sample and $3 \mathrm{ml}$ freshly prepared, precooled, $0.2 \%$ anthrone reagent was taken in a test tube. For insoluble sugar the residue was digested with $5 \mathrm{ml} 25 \% \mathrm{H}_{2} \mathrm{SO}_{4}$ at $80^{\circ} \mathrm{C}$ in a water bath for 30 minutes. The extracted material was taken and diluted 10 times with double distilled water and used as a source of insoluble carbohydrate. After that $1 \mathrm{ml}$ of diluted sample was taken in test tube and insoluble carbohydrate level was determined with $0.2 \%$ anthrone reagent were added. In both cases after 30 minutes the intensity of green colour (OD) was measured in a UV-Visible spectrophotometer at $620 \mathrm{~nm}$. The quantitative estimation was made by using the OD values from a standard curve prepared from glucose and the sugar contents were expressed in $\mathrm{mg} / \mathrm{g}$ fresh tissue.

\subsection{Estimation of MDA content}

The MDA content was estimated using the procedure of Heath and Packer (1968). Freshly collected $100 \mathrm{mg}$ of leaf tissues were homogenized in a $5 \mathrm{ml}$ solution of $1 \%$ Trichloroacetic acid (TCA), followed by centrifugation at $10000 \mathrm{rpm}$ for $5 \mathrm{~min}$. The test solution content $1 \mathrm{ml}$ of enzyme extract and $3 \mathrm{ml}$ of $5 \%$ TCA containing $1 \%$ thiobarbituric acid (TBA) were mixed and the mixture was heated in a hot water bath at $95^{\circ} \mathrm{C}$ for $30 \mathrm{~min}$. The reaction mixture was again centrifuged at $5000 \mathrm{rpm}$ for $5 \mathrm{~min}$. and the absorbance was measure at $532 \mathrm{~nm}$ and $600 \mathrm{~nm}$ in a spectrophotometer against a blank. The non-specific turbidity if any was corrected by subtracting $\mathrm{A}_{600}$ from $\mathrm{A}_{532}$ values. The concentration was calculated from its extension coefficient of $155 \mu \mathrm{M}^{-1} \mathrm{~cm}^{-1}$ by the formula employed as;

$$
\text { MDA content }=\frac{\text { Absorbance } X \text { Total volume }(\mathrm{ml}) \times 100}{\text { Extinction coefficient } \mathrm{X} \text { Vol. of Sample }(\mathrm{ml}) \mathrm{x} \text { weight of Plant tissue }}
$$

The MDA concentration was finally expressed in nmol per $g$ fresh tissue.

\section{Statistical Analysis}

Data were analyzed statistically for determining mean and standard errors and statistical significance using analyses of variance (ANOVA) following Panse and Sukhatme (1978).

\section{Results and Discussions}

Table 1: Root length $(\mathrm{cm})$, shoot length $(\mathrm{cm})$, root-shoot ratio, seedling vigour index and dry weight accumulation/g of fresh weight $(\mathrm{g})$ of seedlings raised from the seeds pretreated with different concentrations of lead $(\mathrm{Pb})$ and cadmium $(\mathrm{Cd})$. [Each value is mean $(n=3) \pm$ S.E.]

\begin{tabular}{|c|c|c|c|c|c|c|}
\hline Treatments & $\begin{array}{c}\text { Concentrations } \\
(\mathrm{mg} / \mathrm{l})\end{array}$ & $\begin{array}{c}\text { Root length } \\
(\mathrm{cm})\end{array}$ & $\begin{array}{c}\text { Shoot length } \\
(\mathrm{cm})\end{array}$ & $\begin{array}{c}\text { Root-Shoot } \\
\text { ratio }\end{array}$ & $\begin{array}{c}\text { Seedling vigour } \\
\text { index }\end{array}$ & $\begin{array}{c}\text { Dry weight accumulation/g } \\
\text { of fresh weight }(\mathrm{g})\end{array}$ \\
\hline Control & 0 & $8.46 \pm 0.02$ & $10.34 \pm 0.02$ & $0.81 \pm 0.004$ & $987.93 \pm 8.41$ & $0.34 \pm 0.004$ \\
\hline \multirow{3}{*}{ Lead } & 5 & $7.85 \pm 0.04$ & $9.29 \pm 0.04$ & $0.84 \pm 0.008$ & $846.59 \pm 11.81$ & $0.32 \pm 0.02^{*}$ \\
\cline { 2 - 7 } & 10 & $6.55 \pm 0.03$ & $9.03 \pm 0.02$ & $0.72 \pm 0.001$ & $782.74 \pm 10.76$ & $0.31 \pm 0.01$ \\
\cline { 2 - 7 } & 15 & $5.82 \pm 0.02$ & $8.53 \pm 0.03$ & $0.68 \pm 0.005$ & $688.15 \pm 7.33$ & $0.29 \pm 0.01$ \\
\hline \multirow{3}{*}{ Cadmium } & 5 & $5.83 \pm 0.04$ & $8.63 \pm 0.04$ & $0.67 \pm 0.001$ & $696.85 \pm 7.47$ & $0.32 \pm 0.01^{*}$ \\
\cline { 2 - 7 } & 10 & $5.63 \pm 0.03$ & $8.05 \pm 0.03$ & $0.69 \pm 0.001$ & $584.85 \pm 14.32$ & $0.30 \pm 0.01$ \\
\cline { 2 - 7 } & 15 & $5.43 \pm 0.06$ & $7.92 \pm 0.04$ & $0.68 \pm 0.004$ & $539.81 \pm 7.27$ & $0.27 \pm 0.01$ \\
\hline CD at 5\% level & & 0.1236 & 0.1373 & 0.2962 & 38.1720 & 0.0420 \\
\hline
\end{tabular}

* Significant at $5 \%$ level 


\section{International Journal of Science and Research (IJSR) \\ ISSN (Online): 2319-7064}

Index Copernicus Value (2015): 78.96 | Impact Factor (2015): 6.391

Table 2: Chlorophyll a and b, carotenoid, free amino acid, protein, soluble and insoluble sugar content of seedlings raised from the seeds pretreated with different concentrations of lead $(\mathrm{Pb})$ and cadmium $(\mathrm{Cd})$. [Each value is mean $(\mathrm{n}=3) \pm \mathrm{S}$.E.]

\begin{tabular}{|c|c|c|c|c|c|c|c|c|}
\hline $\begin{array}{c}\text { Insoluble carbohydrate content } \\
\text { (mg/g of fresh tissue) }\end{array}$ & $9.50 \pm 0.01$ & $13.0 \pm 0.02$ & $18.75 \pm 0.06$ & $11.00 \pm 0.06$ & $9.75 \pm 0.03$ & $18.50 \pm 0.23$ & $8.50 \pm 0.05$ & 0.3869 \\
\hline $\begin{array}{l}\text { Soluble carbohydrate content } \\
\text { (mg/g of fresh tissue) }\end{array}$ & $6.50 \pm 0.06$ & $7.25 \pm 0.06$ & $6.50 \pm 0.05$ & $6.0 \pm 0.02$ & $16.0 \pm 0.14$ & $11.0 \pm 0.05$ & $10.50 \pm 0.05 *$ & 0.2718 \\
\hline $\begin{array}{c}\text { Protein content }(\mathrm{mg} / \mathrm{g} \text { of fresh } \\
\text { tissue }\end{array}$ & $2.15 \pm 0.001$ & $3.15 \pm 0.01$ & $2.55 \pm 0.01$ & $2.50 \pm 0.02$ & $2.95 \pm 0.01$ & $2.70 \pm 0.01$ & $2.30 \pm 0.01$ & 0.0391 \\
\hline $\begin{array}{l}\text { Free amino acid content } 1(\mathrm{mg} / \mathrm{g} \text { of } \\
\text { fresh tissue })\end{array}$ & $1.75 \pm 0.01$ & $1.80 \pm 0.01$ & $2.75 \pm 0.004$ & $1.90 \pm 0.01$ & $2.05 \pm 0.01 *$ & $2.65 \pm 0.01$ & $1.75 \pm 0.01$ & 0.0882 \\
\hline $\begin{array}{c}\text { Carotenoid content ( } \mathrm{mg} / \mathrm{g} \text { of fresh } \\
\text { tissue) }\end{array}$ & $2.14 \pm 0.07$ & $2.09 \pm 0.09$ & $2.0 \pm 0.08$ & $1.97 \pm 0.009$ & $2.11 \pm 0.03$ & $1.95 \pm 0.04$ & $1.89 \pm 0.02$ & 0.3435 \\
\hline $\begin{array}{c}\text { Chlorophyll b content (mg/g of } \\
\text { fresh tissue) }\end{array}$ & $9.24 \pm 0.10$ & $9.0 \pm 0.10$ & $8.93 \pm 0.03$ & $8.67 \pm 0.03$ & $8.54 \pm 0.05$ & $8.54 \pm 0.05$ & $7.66 \pm 0.06$ & 0.2746 \\
\hline $\begin{array}{l}\text { Chlorophyll a content (mg/g of } \\
\text { fresh tissue }\end{array}$ & $8.17 \pm 0.09 *$ & $7.66 \pm 0.14$ & $7.33 \pm 0.12$ & $7.11 \pm 0.12 *$ & $6.94 \pm 0.21 * *$ & $6.94 \pm 0.21 * *$ & $6.25 \pm 0.14$ & 0.5414 \\
\hline Concentration $(\mathrm{mg} / \mathrm{l})$ & 0 & 5 & 10 & 15 & 5 & 10 & 15 & \\
\hline Treatments & Control & \multicolumn{3}{|c|}{ Lead } & \multicolumn{3}{|c|}{ Cadmium } & $\begin{array}{l}\text { CD at } \\
5 \% \text { level }\end{array}$ \\
\hline
\end{tabular}

The results revealed that a gradual decline took place with rise of doses of both the metals in the plant growth at seedling stage. Both lead and cadmium showed negative effects on lengths of root and shoot, seedling vigour index, root-shoot ratio and seedling vigour index. Shoot length and root length are considered as very useful indicator of metal toxicity in plants. Perveen et al. (2011) pointed out that $\mathrm{Cd}$ reduced plant growth as well as plant length, dry weight, possibly by changes in water and nutritional status of plants. The inhibitory effect of $\mathrm{Cd}$ ions on root elongation is mediated through the altered cell growth. After being attached with cell walls and middle lamella, Cd enhances the cross-linking among the wall components inhibiting cell growth as well as root elongation. Prasad (1995) pointed that $\mathrm{Cd}$ affected directly or indirectly on auxin metabolism or auxin carriers resulting inhibition of growth by disturbing cell division and cell expansion.

Result exhibited that there was a decline in chlorophyll and carotenoid content in heavy metals treated plants and cadmium shows the highest effect than the lead in comparison to control. John et al. (2008) pointed out that reasons for declining chlorophyll biosynthesis in plants under $\mathrm{Pb}$ and $\mathrm{Cd}$ stress were (i) inhibition of important enzymes for chlorophyll biosynthesis, such as deltaaminolevulinic acid dehydratase (ALA-dehydratase) and protochlorophyllide reductase. (Van Assche and Clijsters 1990 and Kupper et al., 1996) (ii) adversed effect on the supply of $\mathrm{Mg} 2$ and $\mathrm{Fe} 2+$ required for chlorophyll biosynthesis (iii) deficiency of $\mathrm{Zn} 2+$ resulting in the inhibition of carbonic anhydrase (Van Assche and Clijsters 1990) (iv) Mg2+ ions, which is associated with tetrapyrrole ring of chlorophyll, is replaced by heavy metals. Interference of heavy metals with enzyme protochlorophyllide reductase, inhibit chlorophyll biosynthesis at protochlorophyllide stage (Bhattacharyya and Choudhari, 1994).

Results revealed that content of total free amino acids significantly increased initially and after that decreased at the maximum concentration of both $\mathrm{Pb}$ and $\mathrm{Cd}$. Protein content was also found to increase at the initial concentration of both the $\mathrm{Pb}$ and $\mathrm{Cd}$ after that it was decreased. Protein degradation occurs as a result of increased protease activity (Palma et al., 2002) which was found under stressed conditions. Increase in proteolytic activity in response to heavy metal stress was found by Lee et al. (1976).Some toxic effect of reactive oxygen species due to heavy metal stress, may be the cause of fragmentation of proteins which reduced the protein content. Reasons for reduced levels of protein in the plant raised from seeds pretreated with by heavy metal stress a) reduction in soluble protein level due to extensive hydrolysis of protein b) catalytic activity of different metals c) any stressed conditions d) enhanced protein degradation process e) decreased availability of amino acids and denaturation of enzymes involved in protein synthesis.

Results shows the content of soluble carbohydrate was found to increase initially over the control in $\mathrm{Pb}$ and $\mathrm{Cd}$ treated plants and then decline except $\mathrm{Cd}$ treatment at $15 \mathrm{mg} / \mathrm{l}$ concentration showed the higher content than the control.On the other hand, insoluble carbohydrate increased over the control in $\mathrm{Pb}$ and $\mathrm{Cd}$ treated seedlings with maximum at 10 $\mathrm{mg} / \mathrm{l}$ concentration but it decreased below the content found in control at higher $\mathrm{Cd}$ concentration $(15 \mathrm{mg} / \mathrm{l})$. John et al. (2008) opined that the photosynthetic inhibition or stimulation of rate of respiration probably caused the decrease in total sugar content in plants under $\mathrm{Pb}$ and $\mathrm{Cd}$ stress. Heavy metals react with ribulose bisphosphate carboxylase resulting reduction of carbon metabolism (Stiborova et al., 1987).Reduction in total sugar content of the stressed leaves is due to the inhibition of photosynthesis or stimulation of respiration rate.

Tested heavy metals induced significantly enhancement of lipid peroxidation in a dose dependent manner and cadmium showed the maximum effect. MDA is a low molecular weight end product formed by the decomposition of certain primary and secondary lipid peroxidation, is an oxidative stress indicator (Saffer et al., 2009).Increased Cd concentration is correlated with increased lipid peroxidation. MDA content was markedly affected by the highest concentration of cadmium in Trigonella foenum-graecum $\mathrm{L}$. In lower concentrations Trigonella seedlings showed capability to adapt and produce lower amount of MDA but in higher concentrations MDA concentrations increases in $\mathrm{Cd}$ exposure. The results suggested that heavy metals create excessive generation of superoxide radicals by deficient

\section{Volume 6 Issue 7, July 2017 www.ijsr.net}




\section{International Journal of Science and Research (IJSR) \\ ISSN (Online): 2319-7064}

Index Copernicus Value (2015): 78.96 | Impact Factor (2015): 6.391

antioxidant defenses which result increase in lipid peroxidation and oxidative stress in Trigonella (Bhat et al., 2012).

\section{Conclusion}

The study shows that cadmium had more toxic effect than lead on various growth factors of Trigonella foenumgraecum L. Further research is needed at molecular level to understand theadaptive mechanism of this important medicinal plant under heavy metal stress.

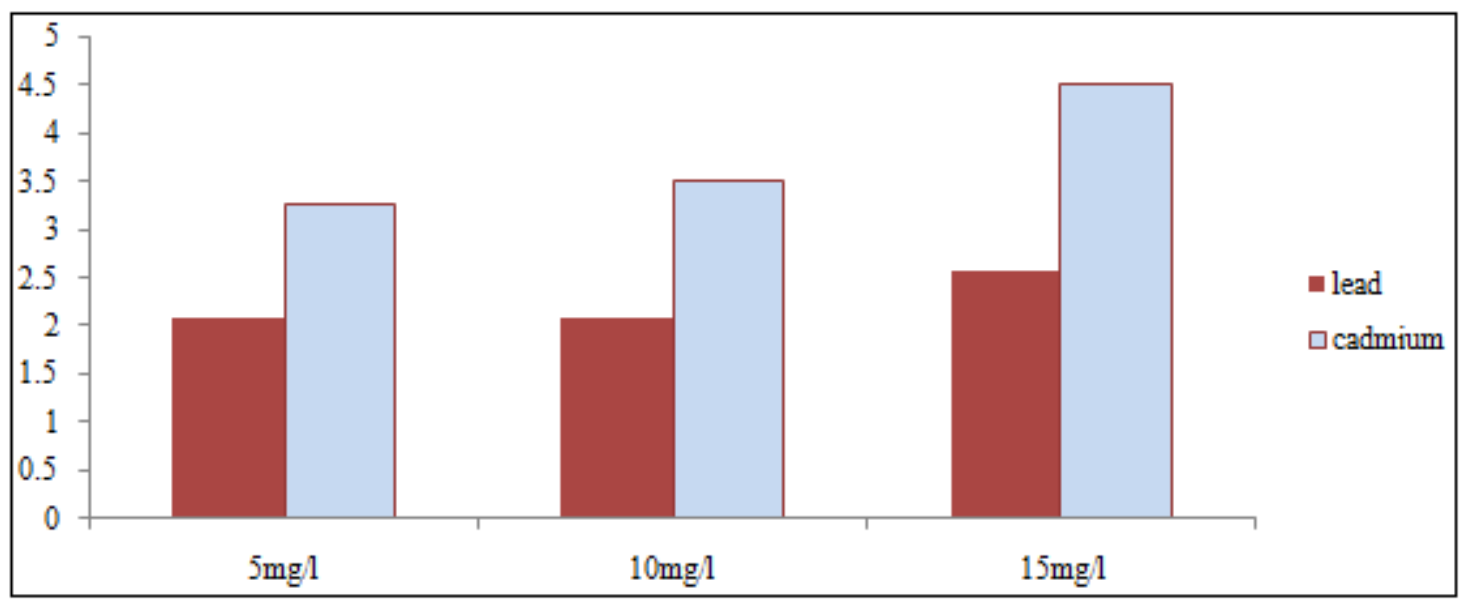

Figure 1: Effect of lead and cadmium on MDA content of the 15 days old leaves.

\section{References}

[1] Arvind P, Prasad MNV (2005) Cadmium zinc interactions in a hydroponic system using Ceratophyllumdemersum L.: adaptive ecophysiology, biochemistry and molecular toxicology. Braz. J. Plant.

[2] Basu., S. (2006) Seed production technology for fenugreek (Trigonella foenumgraecumL.) in the Canadian Prairies. Ph. D. Thesis, Department of Biological Science, University of Lethbridge, Alberta, Canada.

[3] Bhat, T. M., Choudhary, S., Ansari, M. Y. K., Alka and Aslam, R. (2012) Genotoxicity and molecular screening of proteins in root tip cells of Trigonella foenumgraecum (Fenugreek var- Azad) under cadmium stress condition. Int. J. of Plant Phy and Biochem, 4(3), 46-51.

[4] Bhattacharjee, A. (1984) Responses of sunflower plants towards growth retardants with special reference to growth, metabolism and yield. Ph. D. Thesis, Burdwan University, India.

[5] Bhattacharyya, M. and Choudhury, M. A. (1994) Effect of lead and cadmium on the biochemical changes in the leaves of terrestrial (Vigna) and aquatic (Hydrilla) plants under solution culture. Ind. J. Plant Physiol, 37, 99-103.

[6] Costa, G., Spitz, E. (1997) Influence of cadmium on soluble carbohydrates, free amino acids, protein content of in vitro cultured Lupinusalbus. Plant science, 128,131-140.

[7] Dere, S., T. Gunes and R. Sivaci.(1998) Spectrophotometric determination of chlorophyll A, B and total carotenoid contents of some algae species using different solvents. Turk. J. Bot. 22, 13-17.

[8] John, R., Ahmad, P., Gadgil, K. and Sharma, S. (2008) Effect of cadmium and lead on growth, biochemical parameters and uptake in Lemnapolyrrhiza L. Plant soil Environ. 54 (6), 262-270.
[9] Kar, M. and Mishra, D. (1976) Catalase, peroxidase, polyphenol oxidase activities during rice leaf senescene. Plant Physiology. 57, 315-600.

[10] Lee, K. C., Cunningham, B. A., Poulsen, G. M., Laing, G. H. and Moore, R. A. (1976) Effect of cadmium on respiration rate and activities of several enzymes in soybean seedlings. Physiol. Plant. 36, 4-6.

[11] Lichtenthaler, H.K. and Wellburn, A.R. (1985) Determination of total carotenoids and chlorophylls a and $\mathrm{b}$ of leaf in different solvents. Biol. Soc. Trans. 11, 591-592.

[12] Lowry, O.H., Rosebrough, N.J., Farr, A.L., Randall, R.J. (1951) Protein measurement with the folin phenol reagent. J. Biol. Chem. Nov193 (1), 265-275.

[13] McCready, R. M., Guggloz, J., Silvirera, V. and Owens, H. S. (1950) Determination of starch and amylase in vegetables. Analytical Chem. 22, 1156-1158.

[14] Moore, S. and Stein, W. W. (1948) Photometric ninhydrin method for use in chromatography of amino acids. J. of Biol. Chem. 176, 367-388.

[15] Nadkarni, K.M., (1976) Indian Materia Medica, Popular Prakashan, Bombay, 1.

[16] NIN report, (1987). "Use of fenugreek seed powder in the management of non insulin dependent diabetes mellitus" NIN, ICMR, Hyderabad, India,

[17] Palma, J. M., Sandalio, L. M., Javier, C. F., RomeroPuertas, M. C., McCarthy, I. and Del, R. L. A. (2002) Plant proteases protein degradation and oxidative stress: role of peroxisomes. Plant Physiol. Bioche. 40, 521530.

[18] Panse,V.G. and Sukhatme P.V. (1978) Statistical methods for agricultural workers., 3rd Rev.Edn., Indian council of agricultural research, New Delhi.

[19] Perveen, R., Faizan, S., Tiyagi, S.A. and Kausar, S. (2011) Performance of Cd stress condition on growth and productivity parameters of Trigonella foenumfraecum Linn. World J. of Arg. Sci.7 (5), 607-612. 


\section{International Journal of Science and Research (IJSR) \\ ISSN (Online): 2319-7064}

Index Copernicus Value (2015): 78.96 | Impact Factor (2015): 6.391

[20] Prasad, M. N. V. (1995) Cadmium toxicity and tolerance in vascular plants. Environ. Exp. Bot. 35, 525545.

[21] Saffar, A., Najjar, B. M. B. and Mianabadi, M. (2009) Activity of antioxidant enzymes in response to cadmium in Arabidopsis thaliana. J. of Biol. Sci. 9 (1), 44-50.

[22] Seregin, I.V. and Ivanov, V.B. (2001) Physiological Aspect of Cadmium and lead toxic effects on higher plants. Rus. J.of Plant physiology. 48(4):523-544.

[23] Sethy, S.K. and Ghosh, S. (2013): Effect of heavy metals on germination of seeds. J of Nat SciBiol Med .Vol. 4 (2), pp. 272-275.

[24] Stiborova, M., Ditrichova, M. and Brezinova, A. (1987): Effect of heavy metal ions on growth and biochemical characteristics of phosynthesis of barley and maize seedlings. Biol. Plant. Vol. 29, pp. 453-467.

\section{Author Profile}

Mallika Mukherjee was the former research scholar in the Dept. of Botany, The University of Burdwan. 